\title{
Biological Control of Southern Red Mite, Oligonychus ilicis (Acari: Tetranychidae), in Coffee Plants
}

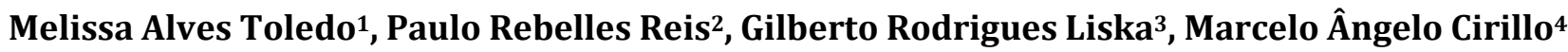 \\ ${ }^{1}$ Entomology Postgraduate Program, Universidade Federal de Lavras-UFLA, Lavras, Minas Gerais, Brazil. \\ ${ }^{2}$ Empresa de Pesquisa Agropecuária de Minas Gerais-EPAMIG Sul/EcoCentro, Lavras, Minas Gerais, Brazil \\ ${ }^{3}$ Universidade Federal do Pampa-UNIPAMPA, Rio Grande do Sul, Brazil \\ ${ }^{4}$ Departamento de Ciências Exatas, Universidade Federal de Lavras-UFLA, Lavras, Minas Gerais, Brazil \\ Email: paulo.rebelles@epamig.ufla.br
}

How to cite this paper: Toledo, M.A., Reis, P.R., Liska, G.R. and Cirillo, M.Â. (2018) Biological Control of Southern Red Mite, Oligonychus ilicis (Acari: Tetranychidae), in Coffee Plants. Advances in Entomology, 6, 74-85.

https://doi.org/10.4236/ae.2018.62007

Received: February 7, 2018

Accepted: March 15, 2018

Published: March 18, 2018

Copyright (c) 2018 by authors and Scientific Research Publishing Inc. This work is licensed under the Creative Commons Attribution International License (CC BY 4.0).

http://creativecommons.org/licenses/by/4.0/

\begin{abstract}
The species of mite Oligonychus ilicis (McGregor) (Tetranychidae) is an important pest of dicotyledonous plants, cosmopolitan and polyphagous, reported in seven countries from four continents, feeding on 34 plant species of 15 families. The spider mite $O$. ilicis is known in Brazil as coffee red spider mite, and as southern red mite most in other countries. In Brazil O. ilicis has been reported as the second most important pest of "Conillon" coffee, Coffea canephora Pierre \& Froehner, in the state of Espírito Santo. Depending on the number of mites per leaf of arabica coffee, Coffea arabica L., the rate of potential photosynthesis can be reduced by $37 \%$ to $50 \%$. In the present study, it was investigated the potential of the two predatory mites which, among others, naturally occurs in coffee plantations, Euseius alatus DeLeon and Amblyseius herbicolus (Chant) (Phytoseiidae), in the control of $O$. ilicis in coffee plants. It was used potted coffee plants in this research, with approximately $100 \mathrm{~cm}$ high, growing in a greenhouse covered with transparent plastic and shading material of $50 \%$ sun protection factor, and with fine mesh on all the sides. Results showed that both species of predatory mites, A. herbicolus and E. alatus, are efficient in reducing the mobile phases-larvae, protonymphs, deutonymphs and adults-of the southern red mite $O$. ilicis. So, the importance of conservation and increase number of these predatory mites in the field coffee growing is essential for implementing the southern red mite integrated management tactic, since these species are of natural occurrence in coffee plants.
\end{abstract}

\section{Keywords}

Agricultural Acarology, Amblyseius herbicolus, Biocontrol, Coffea arabica, 
Euseius alatus, Phytoseiidae

\section{Introduction}

The spider mite Oligonychus ilicis (McGregor) (Acari: Tetranychidae) was first described in 1917, in South Caroline, United States of North America, attacking American Holly trees (Ilex opaca, Ait., Aquifoliaceae); subsequently it was found in plantain (Platanus spp., Platanaceae). This species is considered a pest mite of coniferous, azalea, camellia, and walnut tree in the USA; tea, rice, laurel, and holly in Japan; coffee plant in Brazil, and of several other cultures [1]. Its origin is possibly Far East region of US [2].

The first report of $O$. ilicis attacking coffee trees (Coffea arabica L., Rubiaceae) in Brazil was in the state of São Paulo, in 1950, referred as Paratetranychus ununguis Jacob, together with the mite species Brevipalpus phoenicis (Geijskes) (Acari: Tenuipalpidae), referred as Tenuipalpus phoenicis Geijskes [3].

In Brazil $O$. ilicis has been reported as the second most important pest of "Conillon" coffee, Coffea canephora Pierre \& Froehner, in the state of Espírito Santo [4].

This species is an important pest mite of dicotyledonous plants, cosmopolitan and polyphagous, reported in seven countries from four continents, feeding on 34 plant species of 15 families [5]. It is known in Brazil as coffee red spider [6] or coffee red spider mite [7] and as southern red mite most in other countries [8].

The mite Oligonychus ilicis lives mainly on the upper surface of host plants leaves, which when attacked are covered by a delicate web that is made by the mites themselves and in which waste and dust are retained, giving to the leaves a dirty aspect. The mites can be easily observed with the assistance of a $10 \times$ magnifying glass. The southern red mite punctures the cells of upper surface of leaves and absorbs some of the extravasated cellular content in order to feed themselves; this makes the leaves lose their natural shine and become tanned, which results in plants with a bad visual aspect. The attack usually does not occur in all the plants in the area, the mite presents an aggregate distribution; however, if the conditions are favorable to the pest mite, e.g. dry season of the year, and a control is not performed at the beginning of the infestation, the attack can affect the entire cultivated area [6] [7].

Dry periods, with a prolonged drought, are favorable conditions for the mite development, which may result in falling leaves. As a consequence of the attack, even without falling leaves, the leaf area for photosynthesis is reduced, resulting in the delay of development of new fruits, and in it over all coffee production [9]. Previous studies have indicated a negative correlation between the density of $O$. ilicis and the leaf photosynthetic potential, i.e. the higher the number of pest mite on the leaf, the lower the photosynthesis. At the levels of 15 and 120 pest mite per leaf tested, the rate of photosynthesis was reduced to $37 \%$ and $50 \%$, re- 
spectively [10].

The pest mite $O$. ilicis is usually controlled using acaricides. However, over application of these products causes environmental pollution, hazardous for the applicators, and favors the development of pest mite resistant populations [11] [12]. Thus, it is necessary to evaluate alternative or not conventional methods to control $O$. ilicis in coffee plantations, particularly by means of their natural enemies.

Several natural enemies were found in association with $O$. ilicis in coffee plants, especially predatory mites that belong to Phytoseiidae, Stigmaeidae, and Bdellidae families [13].

Among phytoseiids, the species Euseius alatus DeLeon, Amblyseius herbicolus (Chant), Amblyseius compositus Denmark \& Muma, Iphiseiodes zuluagai Denmark \& Muma are abundant, all of natural occurrence in coffee plants in Brazil; however, a variation in species type and quantity may occur according to the coffee-growing region and time of the year [13]. Another phytoseiid, Euseius concordis (Chant), is also a substantially abundant species in coffee plants in the states of São Paulo and Minas Gerais [14] [15].

Laboratory studies showed that the adult female stage of the I. zuluagai, Euseius citrifolius Denmark \& Muma, and A. herbicolus predatory mites is the most efficient in preying on all phases of $O$. ilicis followed by the phases of nymph, adult male, and larvae, respectively [16]. Considering the phases of $O$. ilicis altogether, the web nest produced by them can reduce the predation potential of I. zuluagai and E. citrifolius, but not that of A. herbicolus [17].

In addition, it has been demonstrated, under laboratory conditions too, that $E$. alatus adult male is also efficient preying on all phases of $O$. ilicis [18].

Also under laboratory conditions, the predatory performance of $E$. concordis preying on $O$. ilicis in densities over $4.3 \mathrm{mites} / \mathrm{cm}^{2}$ is lower than $50 \%$, and above $6.4 \mathrm{mites} / \mathrm{cm}^{2}$ there is a slight decrease in the predation rate and a constancy tendency [19].

Taking into account the facts already exposed, the objective of the present study was to investigate the potential of E. alatus and A. herbicolus as biological control agents of $O$. ilicis on coffee plants under semi-field conditions.

\section{Material and Methods}

The experiment was accomplished in a greenhouse at the Fazenda Experimental da Empresa de Pesquisa Agropecuária de Minas Gerais-EPAMIG Sul, and in the Acarology Laboratories of Centro de Pesquisa em Manejo Ecológico de Pragas e Doenças de Plantas-EcoCentro, in Lavras, Minas Gerais, Brazil.

\subsection{Southern Red Mite Lab Rearing}

Adult mites of $O$. ilicis were collected from leaves o pesticide-free coffee plants (C. arabica) in the municipality of Lavras, state of Minas Gerais, Brazil, taken to the laboratory and reared under controlled conditions at $25^{\circ} \mathrm{C} \pm 2{ }^{\circ} \mathrm{C}$ of temper- 
ature, $70 \% \pm 10 \%$ of $\mathrm{RH}$, and $14 \mathrm{~h}$ of photophase. The mites were reared on detached coffee leaf placed on top of a foam pad of $1 \mathrm{~cm}$ thickness, which occupied the entire bottom of a petri dish of $15 \mathrm{~cm}$ diameter, without a lid. The foam was constantly kept moist with distilled water, and a strip of hydrophilic cotton wool was placed around the leaf to maintain turgidity and act as a physical barrier to prevent the mites from escaping of the arena [20] [21].

\subsection{Predatory Mites Lab Rearing}

The predatory mites, $A$. herbicolus and E. alatus, were collected in the same pesticide-free coffee plants as $O$. ilicis and, in the lab were kept in $9.5 \mathrm{~cm}$ diameter arenas, made of flexible black polyvinyl chloride (PVC), floating on distilled water in $15 \mathrm{~cm}$ diameter Petri dishes, without lid [22]. These arenas were maintained under the same rearing laboratory conditions as described previously for O. ilicis breeding. Predatory mites were fed on pollen of castor bean plant (Ricinus communis L., Euphorbiaceae) and O. ilicis from the lab rearing.

\subsection{Experimental Setup}

Thirty coffee plants (C. arabica) of approximately $100 \mathrm{~cm}$ high, were kept in pots with 20 liters' capacity, in a greenhouse covered with transparent plastic and shading material of $50 \%$ sun protection factor, with fine mesh in all the sides, promoting an ambient temperature of $25^{\circ} \mathrm{C} \pm 5^{\circ} \mathrm{C}$.

For the infestation of coffee plants with pest mite, $40 \mathrm{O}$. ilicis adult females from laboratory rearing were transferred, with aid of a fine-tipped paint brush, to the leaves located in the middle part of each plant, totaling 1,200 adult females.

Twenty days after the infestation with $O$. ilicis, the predatory mites $A$. herbicolus and $E$. alatus were released in a separate experiment for each predatory mite species. There were a total of six treatments for each predatory mite species, each treatment representing an amount of the predatory mite releases set as follow: 0 (control), 2, 4, 6, 8, and 10 predatory mites per coffee plant.

The experimental design was completely randomized, and each treatments being replicated five times.

At 7, 15, 21 and 28 days after predatory mites' release, a leaf of the central part of each plant was detached, totalizing 30 leaves/coffee plant, and taken to the laboratory. The number of all $O$. ilicis mobile phases-larvae, protonymphs, deutonymphs and adults - as well as the number of laid eggs of the pest mite on the leaf surface was recorded under a $40 \times$ binocular stereomicroscope.

Due to the high mobility of the phytoseiid predatory mites on the plants, it was impossible to determine the total number of them, for this reason they were not count.

\subsection{Data Analysis}

Given the specifications of the experiment mentioned above, the number of the $O$. ilicis mobile phases and eggs laid by them on the surface of the leaf were ana- 
lyzed using the methodology of generalized linear models (GLM) [23].

It was proposed the Poisson regression model and was considered a logarithmic linkage function, with a systematic component given by $\eta_{i}=\beta_{0}+\beta_{1} x_{i}+\beta_{2} z_{i}$, with $x_{i}$ the quantity of predators released and $z_{i}$ a categorical variable related to A. herbicolus $\left(z_{i}=0\right)$ and E. alatus $\left(z_{i}=1\right)$ species. Parameters $\beta_{j}$, when $j=$ $0,1,2$, represented the effects associated with each variable and the log-linear linkage function $\log \mu_{i}=\eta_{i}$, being that $\mu_{i}$ represented the mean of the response variable $y_{i}$ in the quantity of predators released $x_{i}$ of species $z_{i}$; i.e. the model that linked the mean number of preys with variables $x^{2} \mathrm{~s}$ and $z$ s is given by Equation (1), considering $\mathcal{E}_{i}$ the experimental error associated with the $i t h$ portion.

$$
\mu_{i}=\mathrm{e}^{\beta_{0}+\beta_{1} x_{i}+\beta_{2} z_{i}}+\varepsilon_{i}
$$

The regression model with a negative binominal response was used, upon occurrence of over dispersed or overlapping responses. This model is the same as Equation (1) and the parameters estimation is similar to what was explained previously. In this case, an additional parameter to the Poisson model was considered and estimated, called dispersion parameter and denoted by $\phi$ [24].

Percentage rates denoted as $\psi$, were calculated with the objective of measuring the effect of a treatment in relation to the control group; considering the reference model obtained when $z=0$ and the model for a given $z$. The percentage rates, or the odds ratio, between the models is given by Equation (2) [25].

$$
\psi=\mathrm{e}^{\beta j}
$$

Therefore, when the species E. alatus was considered, Equation (2) represented a percentage change in the expected number of the prey mite $O$. ilicis that were present on the plant. If $\beta_{j}>0$, an increase in the expected number was entailed and if $\beta_{j}<0$ a decrease in the expected number was entailed; and in this case, it is common to demonstrate Equation (2) as $1-\psi$ [23].

In view of the above, the parameters of the models were estimated with the use of the maximum likelihood method [24], and the validation was carried out through the envelope chart, in order to verify the negative binominal regression model suitability. In addition, under certain conditions of regularity and if the current model describes the data well, the deviance has an asymptotically and approximately chi-square distribution with $n-p$ degrees of freedom, being $n$ the number of observations and $p$ the quantity of parameters that were considered in the model [26].

All the results of the statistical analyses were obtained using the $\mathrm{R}$ statistical software [27].

\section{Results and Discussion}

For further clarification and results interpretation, having the parameters estimation of the adjusted models as the control group, the odds ratio and the parameters significance are described in Table 1 and Table 2. 
Table 1. Parameters estimation of the negative binominal regression model, its respective standard errors and percentage rates $\psi$ between the number of predatory mites released and predatory mite species evaluated, Amblyseius herbicolus and Euseius alatus, for the data of the number of the pest mite Oligonychus ilicis on 30 leaves of coffee plants.

\begin{tabular}{ccccccc}
\hline Variable & Parameter & Estimation & $\begin{array}{c}\text { Standard } \\
\text { error }\end{array}$ & $p$ value & $\psi$ & $\begin{array}{c}1-\psi \\
(\%)\end{array}$ \\
$\begin{array}{c}\text { Deviance } \\
(p \text { value })\end{array}$ \\
\hline Intercept & $\beta_{0}$ & 7.5339 & 0.1543 & $<0.0001$ & & 0.1822 \\
Treatment & $\beta_{1}$ & -0.1842 & 0.0226 & $<0.0001$ & 0.8317 & 16.82 \\
Species & $\beta_{2}$ & 0.1284 & 0.1537 & 0.4040 & 1.1370 & \\
Dispersion & $\phi$ & 3.0790 & 0.6130 & & & \\
\hline
\end{tabular}

Table 2. Parameters estimation of the negative binominal regression model, its respective standard errors and percentage rates $\psi$ between the number of predatory mites released and the predatory mite species evaluated, Amblyseius herbicolus and Euseius alatus, for the data of the number of Oligonychus ilicis laid eggs on 30 leaves of coffee plants.

\begin{tabular}{ccccccc}
\hline Variable & Parameter & Estimation & $\begin{array}{c}\text { Standard } \\
\text { error }\end{array}$ & $p$ value & $\begin{array}{c}\text { 1- } \psi \\
(\%)\end{array} \begin{array}{c}\text { Deviance } \\
(p \text { value })\end{array}$ \\
\hline Intercept & $\beta_{0}$ & 4.6810 & 0.1778 & $<0.0001$ & & 0.1605 \\
Treatments & $\beta_{1}$ & -0.1312 & 0.0280 & $<0.0001$ & 0.8771 & 12.29 \\
Species & $\beta_{2}$ & -0.0026 & 0.1832 & 0.9890 & 0.9974 & 0.25 \\
Dispersion & $\phi$ & 2.3070 & & & & \\
\hline
\end{tabular}

The number of alive $O$. ilicis as the number of predatory mites released was increasing and showed evident variation over the four periods of data collection, especially the 28-day period (Figure 1).

The same is observed for the number of $O$. ilicis eggs, which according to the number of predatory mites released was increased (Figure 2). This fact supports the use of the negative binomial regression model.

\subsection{Total Number of Oligonychus ilicis Mobile Phases}

Considering the total number of $O$. ilicis mobile phases-larvae, protonymphs, deutonymphs and adults-that were alive, it was observed that the species $E$. alatus provided an increase of approximately $13.7 \%$ in the expected number of alive $O$. ilicis in relation to the predatory mite $A$. herbicolus, however, this is not a significant difference, considering a 5\% significance level. Therefore, $E$. alatus showed a similar predation rate to A. herbicolus (Table 1).

When analyzing the number of predatory mites that were released throughout the experiment, it was observed that as the number of predatory mites increased there was a $16.8 \%$ decrease in the expected number of alive $O$. ilicis mobile phases in relation to the previous number (Table 1).

The adjusted model for both predatory mite species, A. herbicolus and E. alatus, considering the number of adults that were released, is shown in Figure 3. A similar behavior between the two predatory mite species was observed, and as the number of predatory mites increases the similarity between the numbers of alive mobile phases of $O$. ilicis is more evident (Figure 3). 


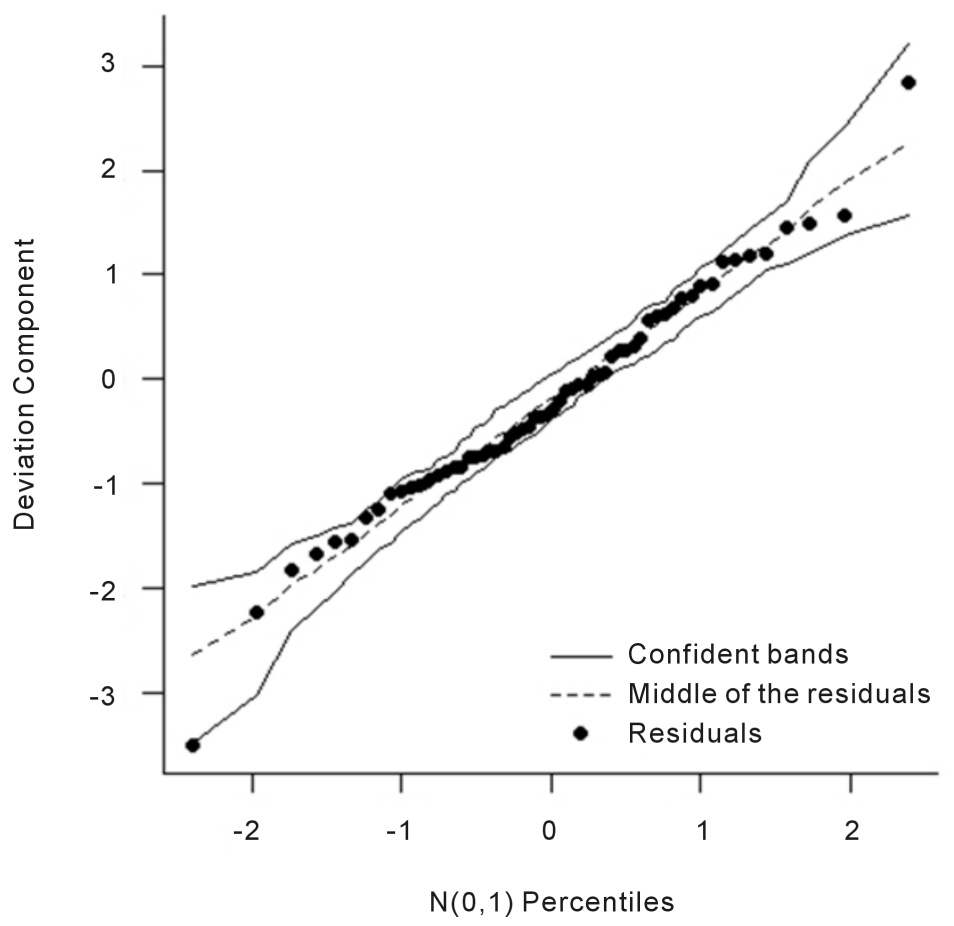

Figure 1. Simulated envelop referring to the negative binominal log-linear model adjusted to the data of Oligonychus ilicis number that were preying on by predatory mite species Amblyseius herbicolus and Euseius alatus, that were released.

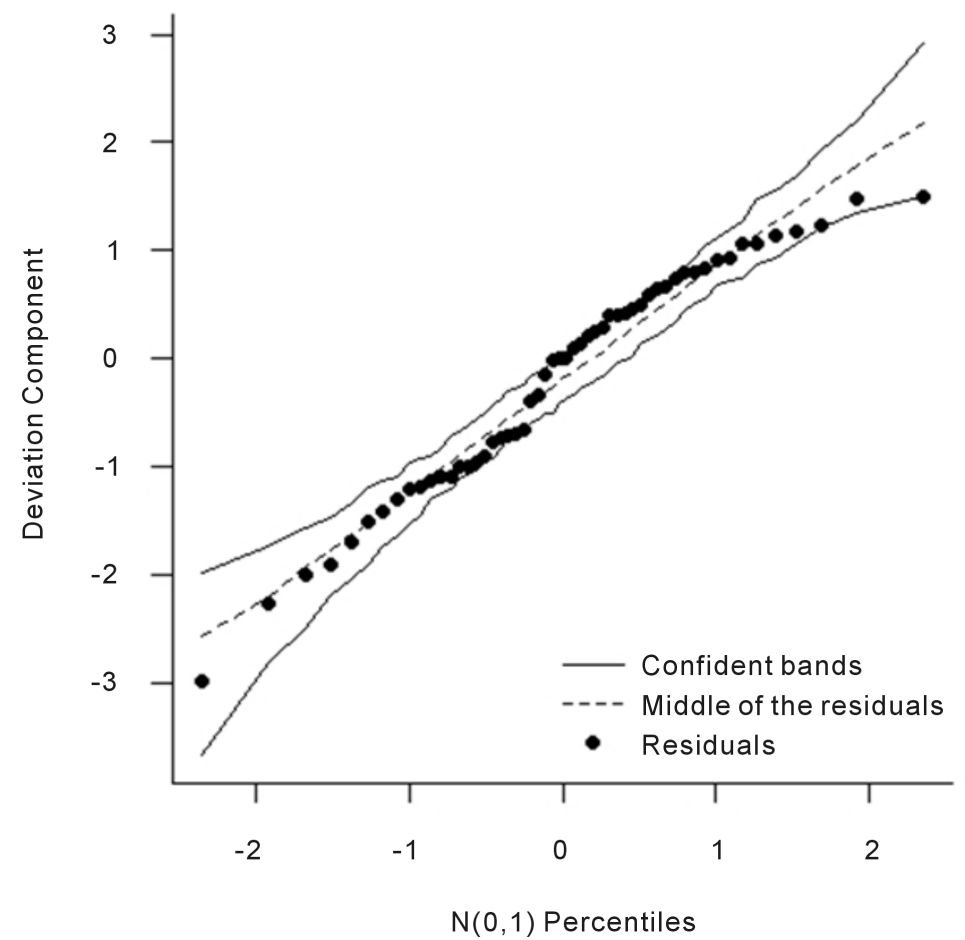

Figure 2. Simulated envelop referring to the negative binominal log-linear model adjusted to the data of laid eggs number by Oligonychus ilicis after the predation of mobile stages by the predatory mite species Amblyseius herbicolus and Euseius alatus, that were released. 


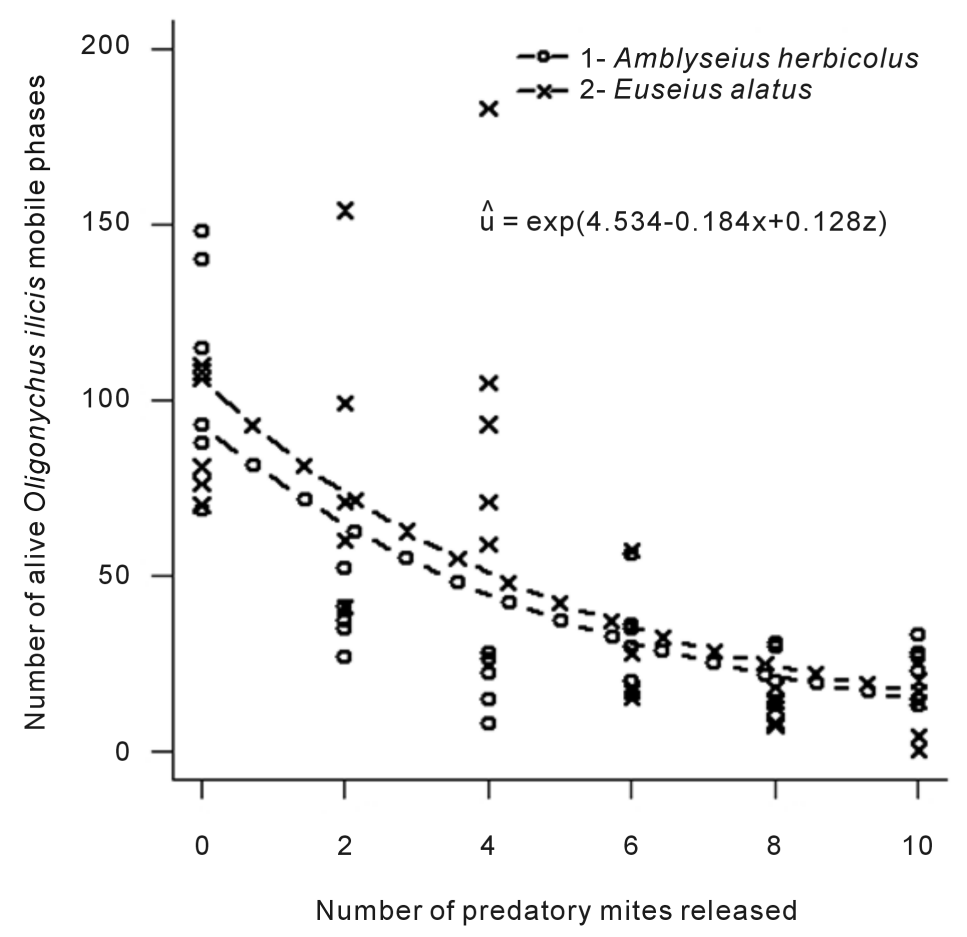

Figure 3. Adjusted model for the number of Oligonychus ilicis mobile phases-larvae, protonymphs, deutonymphs and adults-that were found alive, on 30 leaves of coffee plants, as a function of the number of Amblyseius herbicolus and Euseius alatus predatory mite species that were released.

For both predatory mites, the release of 10 mites per plant provided a more efficient control of $O$. ilicis in coffee plants (Figure 3).

Findings of this study are similar to those already reported in the literature which performed a study with different ratios between the number of Tetranychus urticae Koch (Tetranychidae) and Neoseiulus californicus (McGregor) (Phytoseiidae) on strawberry (Fragaria spp., Rosaceae) and concluded that at ratios of 1:10 (predatory mite/pest) it prevented the pest mite from reaching the economic damage level, i.e. 50 T. urticae/leaflet [28].

It has also been observed that $N$. californicus, when released at ratios of up to 1:10 (predatory mite/pest) was effective in controlling T. urticae too on strawberry too, both in the field and greenhouse, maintaining the pest mite population at low levels for long period [29].

\subsection{Total Number of Laid Eggs by Oligonychus ilicis}

Considering the total number of $O$. ilicis laid eggs, it was observed that the species $E$. alatus caused a reduction of approximately $0.25 \%$ in the expected number of $O$. ilicis eggs in relation to the predatory mite A. herbicolus, however this difference is not significant, considering a $5 \%$ significance level. So, $E$. alatus presented a similar predation rate to $A$. herbicolus when the number of $O$. ilicis laid eggs was also considered (Table 2).

The adjusted model for both predatory mite species in relation to the number 
of $O$. ilicis laid eggs, considering the number of predatory mites released, is shown in Figure 4, where is observed an almost identical behavior between both studied species, $A$. herbicolus and $E$. alatus.

Therefore, the results showed that both predatory mites species, $A$. herbicolus and $E$. alatus, are efficient in reducing the $O$. ilicis mobile phases-larvae, nymph (protonymphs and deutonymphs), and adults-of the southern red mite, in the greenhouse coffee growing (Figure 3 ). These results are also confirmed by the reduction of the number of eggs that were found in the leaves, that is, reduction of the number of eggs placed as a consequence of the reduction of the pest mite number by predation, in addition to the direct predation of the eggs (Figure 4).

This results are similar to those obtained in laboratory studies on the predation potential of the phytoseiid $A$. herbicolus, and other predatory mite species, over several developmental phases of $O$. ilicis, were those showed also that the adult female phase of the predatory mites is the most efficient in predation, followed by the phases of nymph (protonymphs and deutonymphs), adult male, and larvae, respectively [16] [30].

Considering the phases of $O$. ilicis altogether, webbing reduced the predation potential of I. zuluagai and E. citrifolius predatory mites, but not of $A$. herbicolus [17] studied in this work.

It has been demonstrated also under laboratory conditions that E. alatus adult male is an efficient predatory mite of $O$. ilicis in all its developmental phases [18], result also found in this study in the greenhouse coffee growing.



Figure 4. Adjusted model for the number of laid eggs by Oligonychus ilicis, on 30 leaves of coffee plants, after the predation of mobile phases-larvae, protonymphs, deutonymphs and adults-and as a function of the number of Amblyseius herbicolus and Euseius alatus predatory mite species that were released. 
Initial infestations of 15 - 120 females of $O$. ilicis per coffee leaf can result in a significant decrease in photosynthesis, causing substantial damage to coffee crops [10]. As the present result indicates, E. alatus and A. herbicolus would be capable of controlling the population of $O$. ilicis before it would reach such damaging level, what show the importance of conservation and augmentation of this biological control agent in the coffee growing field.

Releases of the predatory mites $A$. herbicolus and $E$. alatus efficiently reduced $O$. ilicis populations on greenhouse-grown and the strategy of the conservative biological control in the field coffee growing is also essential for implementing the southern red mite integrated management tactic, since this species is of natural occurrence in coffee plants, as already reported in the literature [13] [14] [15]. In addition, considering the main control method adopted by the coffee producers, i.e., the use of plant protection products, those products that present some type of selectivity might be prioritized, which would maintain predatory mites that are natural enemies of the southern red mite.

Among the most successful biocontrol programs in the world are those of mite control, implemented in plants grown under greenhouse or field. Brazil is starting in this practice of control, but still have limited and demand for information on the interactions of predatory mite/prey in different production systems are necessary.

Because they are of naturally occurrence in coffee plants, the strategy of conservation and increase of predatory mites is essential to the tactics of integrated management of the southern red mite. If necessary the use of plant protection chemical products should be prioritized those that show some type of selectivity, thus preserving the predatory mites, natural enemies of pest mites.

\section{Acknowledgements}

To the Conselho Nacional de Desenvolvimento Científico e Tecnológico-National Council for Scientific and Technological Development-CNPq, and Coordenação de Aperfeiçoamento de Pessoal de Nível Superior-Coordination for the Improvement of Higher Education Personnel-CAPES, for financial support and fellowships granted.

\section{References}

[1] Jeppson, L.R., Keifer, H.H. and Baker, E.W. (1975) Mites Injurious to Economic Plants. University of California Press, Berkeley, 614 p.

[2] Pritchard, A.E. and Baker, E.W. (1955) A Revision of the Spider Mite Family Tetranychidae. The Pacific Coast Entomological Society, San Francisco, 472 p.

[3] Amaral, J.F. (1951) O ácaro dos cafezais. Boletim da Superintendência dos Serviços do Café, 26, 846-848.

[4] IBC-Instituto Brasileiro do Café (1985) Cultivo de café Conilon. In: IBC, Ed., Cultura do café no Brasil: Manual de recomendação, IBC-GERCA, Rio de Janeiro, 527-556.

[5] Bolland, H.R., Gutierrez, J. and Flechtmann, C.H.W. (1998) World Catalogue of the 
Spider Mite Family (Acari: Tetranychidae). Brill Academic Publishers, Leiden, 1998, $392 \mathrm{p}$.

[6] Calza, R. and Sauer, H.F.G. (1952) A aranha vermelha dos cafezais. Biológico, 18, 201-208.

[7] Reis, P.R. and Zacarias, M.S. (2007) Ácaros em cafeeiro. EPAMIG, Belo Horizonte, 76 p. (Boletim Técnico, 81).

http://www.epamig.br/download/bt81-acaros-em-cafeeiro/

[8] CSIRO (2015) Commonwealth Scientific and Industrial Research Organization. Australian Insect Common Names.

http://www.ces.csiro.au/aicn/name_c/a_3931.htm

[9] Reis, P.R. and Souza, J.C. (1986) Pragas do cafeeiro, p. 323-378. In: Rena, A.B., Malavolta, E., Rocha, M. and Yamada, T., Eds., Cultura do cafeeiro: fatores que afetam a produtividade, Piracicaba, Potafós, $447 \mathrm{p}$.

[10] Franco, R.A., Reis, P.R., Zacarias, M.S., Altoé, B.F. and Barbosa, J.P.R.A.D. (2009) Influência da infestação de Oligonychus ilicis (McGregor, 1917) (Acari: Tetranychidae) sobre a taxa de fotossíntese potencial de folhas de cafeeiro. Arquivos do Instituto Biológico, 76, 205-210.

https://www.alice.cnptia.embrapa.br/alice/bitstream/doc/880356/1/Influenciadainfe stacao.pdf

[11] Stumpf, N. and Nauen, R. (2001) Cross-Resistance, Inheritance and Biochemistry of Mitochondrial Electron Transport Inhibitor-Acaricide Resistance in Tetranychus urticae (Acari: Tetranychidae). Journal of Economic Entomology, 94, 1577-1583. https://doi.org/10.1603/0022-0493-94.6.1577

[12] Nicastro, R.L., Sato, E.M. and Silva, M.Z. (2010) Milbemectin Resistance in Tetranychus urticae (Acari: Tetranychidae) Selection, Stability and Cross-Resistance to Abamectin. Experimental and Applied Acarology, 50, 231-241. https://doi.org/10.1007/s10493-009-9304-9

[13] Reis, P.R. (2002) Brevipalpus phoenicis, ácaro vetor da mancha-anular em cafeeiro: Biologia, dano e controle. In: Encarnação, R.O., Afonso Júnior, P.C. and Rufino, J.L.S., Eds., Simpósio de Pesquisa dos Cafés do Brasil, Embrapa Café, Brasília, 257-280. http://www.sbicafe.ufv.br/handle/123456789/527

[14] Mineiro, J.L.C., Sato, M.E., Raga, A., Arthur, V., Moraes, J.G., Sarreta, F.O. and Carrijo, A. (2006) Diversidade de ácaros (Arachnida: Acari) em Coffea arabica L. cv. Mundo Novo, nos municípios de Jeriquara e Garça, Estado de São Paulo. Biota Neotropica, 6, 1-15. https://doi.org/10.1590/S1676-06032006000200012 http://www.biotaneotropica.org.br/v6n2/pt/abstract?article+bn01106022006

[15] Franco, R.A., Reis, P.R., Zacarias, M.S., Altoé, B.F. and Pedro Neto, M. (2008) Dinâmica populacional de Oligonychus ilicis (McGregor, 1917) (Acari: Tetranychidae) em cafeeiro e de fitoseídeos associados a ele. Coffee Science, 3, 38-46.

[16] Franco, R.A., Reis, P.R., Zacarias, M.S. and Altoé, B.F. (2007) Potencial de predação de três espécies de fitoseídeos sobre Oligonychus ilicis (McGregor, 1917) (Acari: Tetranychidae). Coffee Science, 2, 175-182.

[17] Franco, R.A., Reis, P.R., Zacarias, M.S. and Oliveira, D.C. (2010) Influência da teia de Oligonychus ilicis (McGregor) (Acari: Tetranychidae) sobre os fitoseídeos predadores associados. Neotropical Entomology, 39, 97-100. https://doi.org/10.1590/S1519-566X2010000100013

[18] Toledo, M.A., Reis, P.R., Silveira, E.C., Marafeli, P.P. and Souza-Pimentel, G.C.S. (2013) Predatory Potential of Euseius alatus (Phytoseiidae) on Different Life Stages of Oligonychus ilicis (Tetranychidae) on Coffee Leaves under Laboratory Condi- 
tions. Neotropical Entomology, 42, 185-190. https://doi.org/10.1007/s13744-012-0100-6

[19] Liska, G.R., Silveira, E.C., Reis, P.R., Cirillo, M.A. and Gonzalez, G.G.H. (2015) Seleção de um modelo de regressão binomial para taxa de predação de Euseius concordis (Chant, 1959). Coffee Science, 10, 113-121.

[20] McMurtry, J.A. and Scriven, G.T. (1965) Insectary Production of Phytoseiid Mites. Journal of Economic Entomology, 58, 282-284. https://doi.org/10.1093/jee/58.2.282

[21] Reis, P.R., Alves, E.B. and Sousa, E.O. (1997) Biologia do ácaro-vermelho do cafeeiro Oligonychus ilicis (McGregor, 1917). Ciência e Agrotecnologia, 21, 260-266.

[22] Reis, P.R. and Alves, E.B. (1997) Criação do ácaro predador Iphiseiodes zuluagai Denmark \& Muma (Acari: Phytoseiidae) em laboratório. Neotropical Entomology Formerly Anais da Sociedade Entomológica do Brasil, 26, 565-568. https://doi.org/10.1590/S0301-80591997000300021

[23] Hosmer, D.W., Lemeshow, S. and Sturdivant, R.X. (2013) Applied Logistic Regression. 3rd Edition, Wiley Series in Probability and Statistics, New York, 528 p. https://doi.org/10.1002/9781118548387

[24] Jiang, J. (2007) Linear and Generalized Linear Mixed Models and Their Applications. Springer Series in Statistics, New York, 257 p.

[25] Cummings, P. (2008) Methods for Estimating Adjusted Risk Ratios. The Stata Journal, 9, 175-196. http://www.stata-journal.com/sjpdf.html?articlenum=st0162

[26] McCulloch, C.E., Searle, S.R. and Neuhaus, J.M. (2008) Linear, Generalized, and Mixed Models. 2nd Edition, Wiley Series in Probability and Statistics, New York, $424 \mathrm{p}$.

[27] Greco, N.M., Sánchez, N.E. and Liljesthrom, G.G. (2005) Neoseiulus californicus (Acari: Phytoseiidae) as a Potential Control Agent of Tetranychus urticae (Acari: Tetranychidae): Effect of Pest/Predator Ratio on Pest Abundance on Strawberry. Experimental and Applied Acarology, 37, 57-66. https://doi.org/10.1007/s10493-005-0067-7

[28] R Core Team (2015) R: A Language and Environment for Statistical Computing. R Foundation for Statistical Computing, Vienna. http://www.R-project.org/

[29] Fraulo, A.B. and Liburd, O.E. (2007) Biological Control of Twospotted Spider Mite, Tetranychus urticae, with Predatory Mite, Neoseiulus californicus, in Strawberries. Experimental and Applied Acarology, 43, 109-119. https://doi.org/10.1007/s10493-007-9109-7

[30] Reis, P.R., Teodoro, A.V., Pedro Neto, M. and Silva, E.A. (2007) Life History of Amblyseius herbicolus (Chant) (Acari: Phytoseiidae) on Coffee Plants. Neotropical Entomology, 36, 282-287. https://doi.org/10.1590/S1519-566X2007000200016 